\title{
Design Study of Thorium Cycle Based Long Life Modular Boiling Water Reactors
}

\author{
Nuri Trianti ${ }^{1)}$, Zaki Su'ud ${ }^{1)}$, and Eka Sapta Riyana ${ }^{2)}$ \\ ${ }^{1)}$ Nuclear Physics and Biophysics Research Division \\ Faculty of Mathematics and Natural Sciences \\ Institut Teknologi Bandung, Indonesia \\ ${ }^{2)}$ Nuclear Energy Regulatory Agency (BAPETEN), Jakarta \\ e-mail:szaki@fi.itb.ac.id,nuri.trianti@gmail.com
}

Received 6 July 2011, Revised 5 September 2011, Accepted 20 September 2011

\begin{abstract}
Design study of long life (cycle) Boiling Water Reactor, which can be operated for 20-30 years of operation time without the necessity of refuelling during that period, has been performed. In shown in the previous study Th232U233 cycle based fuel has potential for longer operation time in the thermal reactor domain. To increase reactor operation time and minimize excess-reactivity burnable poison may be used. Protactinium (Pa-231), Np-238, or gadolinium has good properties for such purpose. Here based on the previous study we select Protactinium and Gadolinium poisons to be used in the present study. Optimizations the content of ${ }^{231} \mathrm{~Pa}$ in the core enables the BWR core to sustain enough reactivity for long period of time with reasonable burn-up reactivity swing. Based on the optimization of fuel element composition (Th and $\mathrm{Pa}$ ) in various moderation compositions can be achieved reactor core with longer operation time, $20 \sim 30$ years operation without fuel shuffling or refuelling. Similarly Gadolinium has been successfully used to extend refuelling time and reduce excess reactivity during burnup period for both oxide fuel and nitride fuel.
\end{abstract}

Keywords: Th-232, U-233, Pa-231, BWR, gadolinium, tight lattice, long life core

\section{Introduction}

Long life modular reactors without onsite refuelling become important candidates for next generation nuclear power reactors suitable for remote area. Learning from Chernobyl and Fukushima nuclear accidents it is important to reduce excess reactivity during burn-up passively and also enhance natural circulation of the coolant or alternative system for decay heat removal system ${ }^{1-3)}$.

Thorium cycle in general has larger conversion ratio in the thermal neutron spectrum domain than uranium cycle so that it has potential for long life operation and at the same time reducing maximum excess reactivity during reactor operation ${ }^{1,2,4)}$. Reducing maximum excess reactivity during burnup may reduce the risk of severe accident such as in the case of Chernobyl accident.

In the long-life operation for modular reactors it is usually related to smaller average power density and higher natural circulation component during their operation. Therefore it can help avoiding severe accident due to decay heat removal failure during station blackout accident such as in the case of Fukushima nuclear accident.

\section{Calculation Method}

In this study multi groups diffusion calculation is performed using CITATION code FI-ITB CH1 code, while burn-up calculations are performed inside the fuel cell using PIJ modules in SRAC code system $^{5}$.
BWR design general specification in this study adopted from standard specification of BWR-6 as seen on Table 1.

Table 1. General specification of Reactor Design

\begin{tabular}{lc}
\hline \multicolumn{1}{c}{ Parameters } & Specifications \\
\hline Power (thermal) & $100 \mathrm{MW}-600 \mathrm{MW}$ \\
Refuelling period & over 29 years \\
Core geometry & Cylinder Balance \\
Core characteristic & Small-long life core \\
Fuel & Th-U oxide Th-Pa-U \\
& oxide \\
Cladding & Zircalloy $(\mathrm{Zr})$ \\
Coolant & Light water $\left(\mathrm{H}_{2} \mathrm{O}\right)$ \\
Smear density & $90 \% \mathrm{~T} . \mathrm{D}$. \\
Fuel density & $11.6 \mathrm{~g} / \mathrm{cm}^{3}$ \\
Average density of $\mathrm{H}_{2} \mathrm{O}$ & $0.76 \mathrm{~g} / \mathrm{cm}^{3}$ \\
Average density of $\mathrm{H}_{2} \mathrm{O}$ & $0.0377 \mathrm{~g} / \mathrm{cm}^{3}$ \\
vapour & \\
Void composition & $0-40 \%$ \\
Operational pressure & $71.94 \mathrm{bar}$ \\
Pin cell type & Square cell \\
Pin pitch & $1.62 \mathrm{~cm}$ \\
\hline
\end{tabular}

Each neutron has different energy level, i.e. about $10 \mathrm{MeV}$ to $10^{-5} \mathrm{eV}$. In this study, energy spectrum is divided into 5 energy groups such we can see on Table 2. Fast energy group is divided into 3 groups, while thermal energy region is divided into two energy groups. BWR used in this study is thermal 
reactor, but the fuels used in this study also accommodate under moderated fuel condition, so that we looked after the range of epithermal neutron energy.

Table 2. Energy Grouping

\begin{tabular}{ccc}
\hline Energy & Group & Energy Range \\
\hline Fast & Group 1 & $10 \mathrm{MeV}-0.1831$ \\
& & $\mathrm{MeV}$ \\
& Group 2 & $0.1831 \mathrm{MeV}-$ \\
& & $961.12 \mathrm{eV}$ \\
& Group 3 & $961.12 \mathrm{eV}-2.382$ \\
& & $\mathrm{eV}$ \\
\hline Thermal & Group 4 & $2.382 \mathrm{eV}-0.256 \mathrm{eV}$ \\
& Group 5 & $0.256 \mathrm{eV}-10^{-5} \mathrm{eV}$ \\
\hline
\end{tabular}

Fuel specification used in this study could be seen in Table 3. Fuel geometry in this study was square cell type. In SRAC program, cell geometry shape coded with IGT code, IGT $=4$ was the code for square cell. Square cell fuel divided into 7 regions, 3 regions was fuel's region, the third region was cladding's region, and 3 last regions was moderator's region.

Th-Pa-U oxide has higher boiling and melting point than nitride compound, but it has smaller thermal conductivity. This advantage is enough to cover its disadvantage.

Table 3. Fuel Design Specifications

\begin{tabular}{lc}
\hline \multicolumn{1}{c}{ Parameters } & Specifications \\
\hline Pin cell type & Square cell \\
Fuel & Th-Pa-U oxide \\
Structure materials & $\mathrm{Zr}$ \\
Moderator & $\mathrm{H}_{2} \mathrm{O}$ \\
Cladding thickness & $1 \mathrm{~mm}$ \\
U-233 Enrichment & $8-13$ \\
Burnable Poisons (\%) & $6-16$ \\
Pa-231 & \\
Fuel fraction (\%) & $50-60$ \\
Power density & $19-40$ \\
(watt/cc) & \\
Pin pitch (cm) & 1.62
\end{tabular}

About core design specifications, the core is balanced cylinder type divided into 3 radial regions and 11 axial regions. First radial region was region for placing the inner fuel, second region was the place for outer fuel and the last region was reflector region.

The SRAC calculation scheme used in this study is shown in Figure 1. The calculations use PIJ module and Citation module.

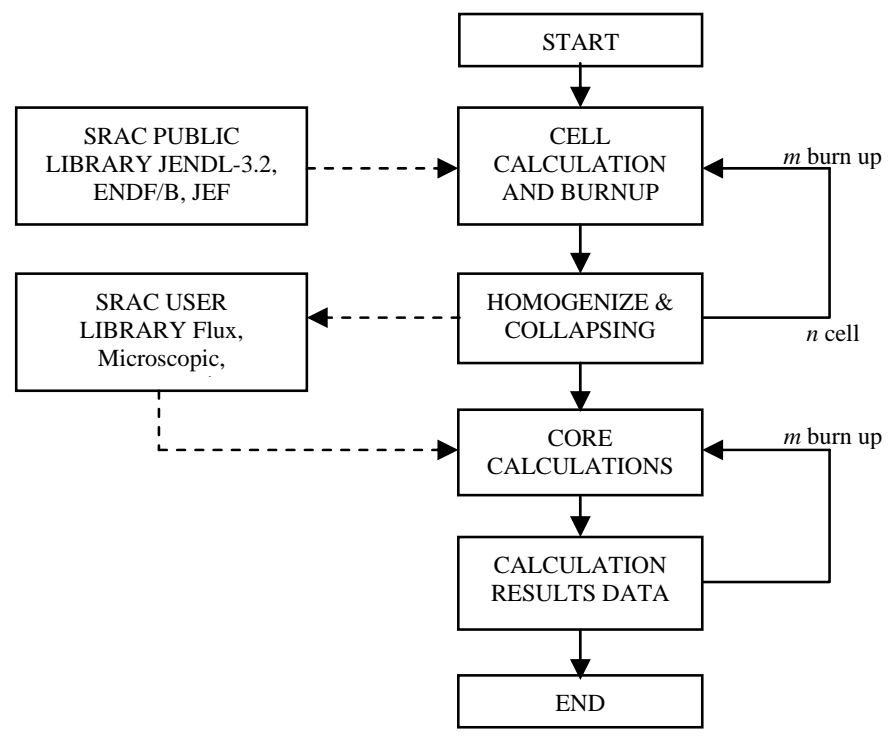

Figure 1. Block diagram of reactor design calculations with SRAC

\section{Calculation Results and Discussions}

Reactor which was used in this study consists of heterogeneous fuel to flatten power distribution for reactor core. General specification of BWR reactor design described as below (Table 4).

Selected core geometry could be seen in Figure 2. We use inner core fuel with composition $8.1 \%{ }^{233} \mathrm{U}$ and $6.7 \%{ }^{231} \mathrm{~Pa}$, and outer core with composition $11 \%$ ${ }^{233} \mathrm{U}$ and $12.5 \%{ }^{231} \mathrm{~Pa}$. Fuel composition on reactor core could be seen in Figure 4. The core height is $252.72 \mathrm{~cm}$, active core diameter is $298.06 \mathrm{~m}$, the whole height of the core including reflector is $317.62 \mathrm{~cm}$ while the whole diameter of the core and reflector is $362.86 \mathrm{~cm}$

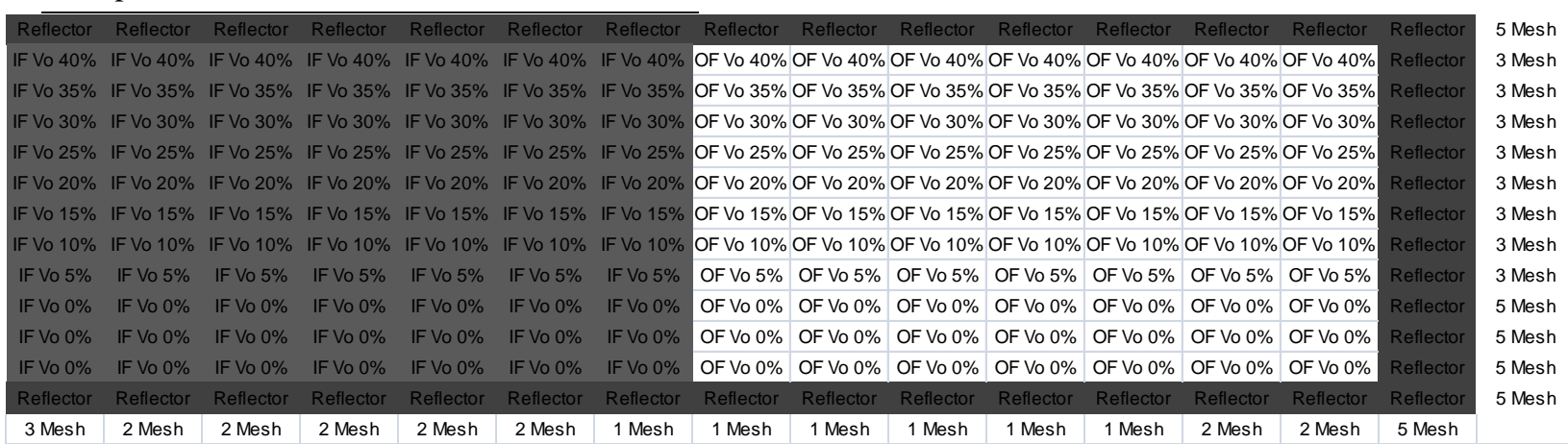

Figure 2. Heterogeneous fuel composition 
Table 4. General Specification of BWR Core Design

\begin{tabular}{lc}
\hline \multicolumn{1}{c}{ Parameters } & Specifications \\
\hline Power (thermal) & $90 \mathrm{MW}-720 \mathrm{MWyr}$ \\
Refuelling period & $25-30$ years \\
Fuel & Th-Pa-U oxide \\
Shielding material & Zircalloy $(\mathrm{Zr})$ \\
Coolant & Light water $\left(\mathrm{H}_{2} \mathrm{O}\right)$ \\
U-232 percentage & $8.1 \%-11 \%$ \\
Pa-231 percentage & $6.7 \%-12.5 \%$ \\
Fuel volume, cladding, & $60 \%-20 \%-20 \%$ \\
and moderator fraction & \\
Moderation void range & $0-40 \%$ \\
Power density & $17.6-44 \mathrm{Watt} / \mathrm{cc}$ \\
Pin pitch & $1.62 \mathrm{~cm}$ \\
Core geometry & Cylinder Balance \\
Cell geometry & Square cell \\
\hline
\end{tabular}

One mesh has $6.48 \mathrm{~cm}$ of size, inner fuel zones have $90.72 \mathrm{~cm}$ of radii, and outer fuel thickness 58.32 $\mathrm{cm}$. Vertical zone about 15 mesh $(97.2 \mathrm{~cm})$ was zone with $0 \%$ void (water without bubbles), 3 mesh (19.44 $\mathrm{cm})$ was zone with $5 \%$ void. Immediately with void interval $5 \%$ to $40 \%$, 3 mesh $(19.44 \mathrm{~cm})$, respectively. Thickness of reflector was $30 \mathrm{~cm}$ for radial and axial directions.

The differences of U-233 enrichment between inner fuel and outer fuel employed due to power density for each region on radial direction relatively are the same so that power peaking from reactor could be reduced. Meanwhile, the enrichment on axial direction was not distinguished due to reactor safety still preserved though blockage on coolant flow occurred. Consequently, power distribution on axial direction will not flat.

Void was an important factor that gives an effect to k-eff values. Figure 2 showed up the effect of void to k-eff values. In this reactor design, we assumed that axial direction void composition in the core on $0-40 \%$ of range, both the range and the number of void composition was time-independent; this assumption was taken to simplify analysis.

Figure 2 showed up that this void parameter has strong effect on the fuel neutronics characteristics. This void effect looked bigger on the beginning of fuel operation (BOL) and smaller on the end of fuel burn-up period (EOL). The higher void fraction provides the smaller k-eff values on the BOL.

Optimized results of reactor core could be seen in Table 5. It is shown that U233 enrichment about eight and eleven percents are used in the inner and outer core regions. And high fuel volume fraction of $60 \%$ is used to improve criticality due to smaller size of the core than the conventional BWR cores. Much smaller coolant volume fraction of $20 \%$ than that of the conventional BWR is used due to smaller power density and to improve conversion ratio.

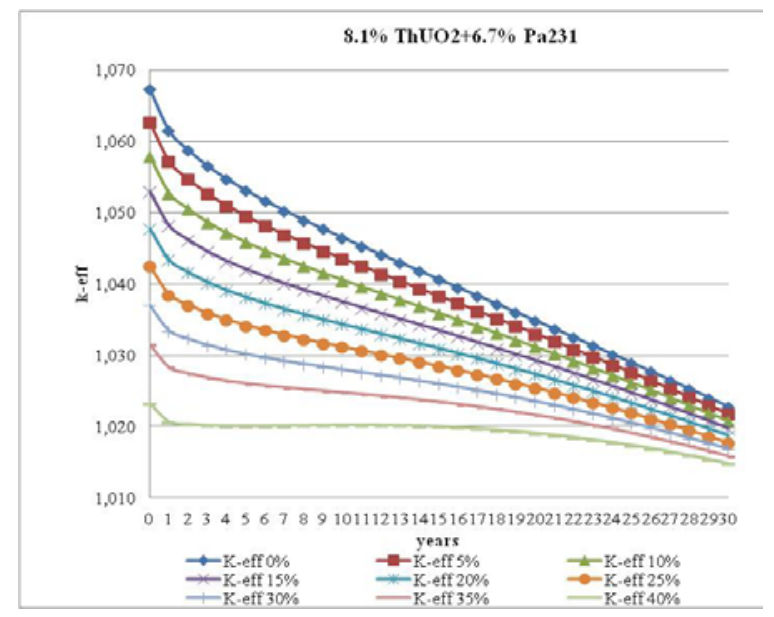

Figure 3. k-eff versus time graphic of $8.1 \%$ Th-U-O $\mathrm{O}_{2}$ and $6.7 \%{ }^{231} \mathrm{~Pa}$

Table 5. Design specifications of BWR core

\begin{tabular}{lc}
\hline \multicolumn{1}{c}{ Parameters } & Specifications \\
\hline Power (thermal) & $620 \mathrm{MWyr}$ \\
Refuelling period & 30 years \\
Fuel & Th-Pa-U oxide \\
Shielding material & Zircalloy $(\mathrm{Zr})$ \\
Coolant & Light water $\left(\mathrm{H}_{2} \mathrm{O}\right)$ \\
U-233 percentage & $8.1 \%$ and $11 \%$ \\
Pa-231 percentage & $6.7 \%$ and $12.5 \%$ \\
Fuel volume, cladding, & $60 \%-20 \%-20 \%$ \\
and moderator fraction & \\
Moderation void range & $0-40 \%$ \\
Reactivity excess & $0.384 \%$ \\
Power density & $17.6-44 \mathrm{Watt} / \mathrm{cc}$ \\
Active volume (litres) & $17,635.8$ \\
\hline
\end{tabular}

Table 6. General design parameter for system using Gadolinium

\begin{tabular}{lc}
\hline \multicolumn{1}{c}{ Parameter } & Value \\
\hline Fuel volume fraction & $60 \%$ \\
\hline $\begin{array}{l}\text { Coolant volume } \\
\text { fraction(H2O) }\end{array}$ & $20 \%$ \\
\hline $\begin{array}{l}\text { Cladding volume } \\
\text { fraction(Zircaloy ) }\end{array}$ & $20 \%$ \\
\hline Axial void fraction & $0-40 \%$ \\
\hline Fuel type & $(\mathrm{ThU}) \mathrm{O}_{2}$ dan ThN \\
\hline Pitch & $1,62 \mathrm{~cm}$ \\
\hline Fuel to Fuel Distance & $1 \mathrm{~mm}$ \\
\hline Linear Power Level & $40 \mathrm{watt} / \mathrm{cm}$ \\
\hline $\begin{array}{c}\text { Average Power Density } \\
\text { Cell }\end{array}$ & $18 \mathrm{watt} / \mathrm{cc}$ \\
\hline
\end{tabular}

Figure 4 show infinite multiplication change during burn-up of nitride fuels for various gadolinium addition with $8 \%$ U-233 enrichments. In general the addition of gadolinium reduce overall excess 
reactivity during burn-up but also reduce the reactivity swing. Figure 5 shows the effect of void fraction in the k-inf change during burnup for $8 \% \mathrm{U} 233$ and $10 \%$ Gd 157 nitride fuels. It is shown that the higher the void fraction the higher the k-inf values during burnup. It is shown that the gadolinium absorption has strong effect and for higher void fraction the spectrum is shifted to the epithermal region and the effective cross section of Gd-157 is reduced.

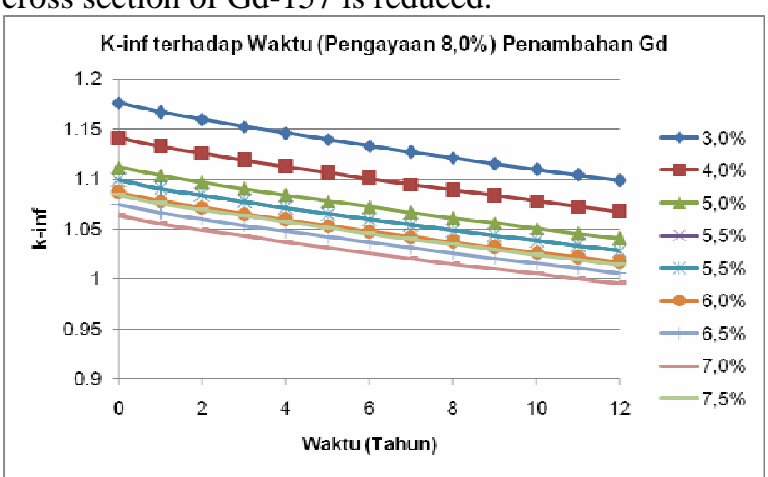

Figure 4. Infinite multiplication factor changes for various gadolinium addition for the nitride fuel with 8\% U233

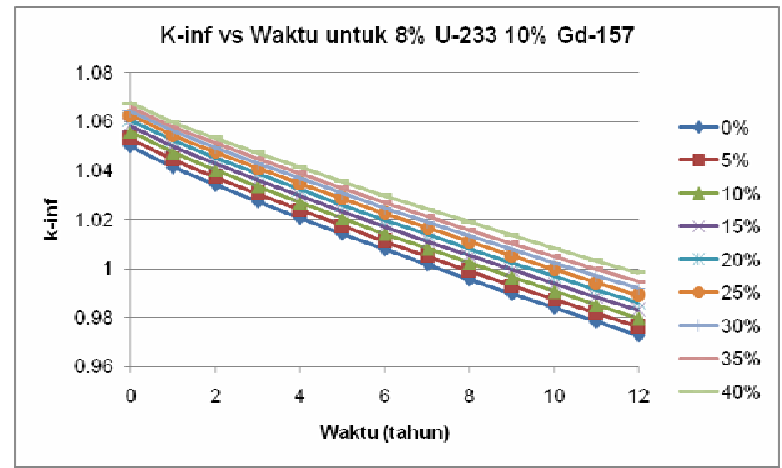

Figure 5. The effect of void fraction to the infinite multiplication change during burnup for the nitride fuel based system with 8\%U233 and 10\% Gd-157

Finally Table 7 shows optimal design using $\mathrm{U}^{233}$-Th-Gd nitride fuel system based long life BWR. It is shown that 12 years life time without refuelling can be reached with maximum excess reactivity of about $0.4 \% \mathrm{dk} / \mathrm{k}$ can be reached.

Table 7. Optimized Design specifications of BWR core with U233-Th232-Gd157 fuel

\begin{tabular}{lc}
\hline \multicolumn{1}{c}{ Parameter } & Value \\
\hline \hline Power & 620 MWth \\
\hline \hline Refueling interval & 12 tahun \\
\hline \hline Shielding material & Zircalloy \\
\hline Coolant & Light water $(\mathrm{H} 20)$ \\
\hline Fuel & Th-Gd-U nitride \\
\hline Gd-157 percentage & $8 \%$ dan $9 \%$ \\
\hline Fuel, cladding and coolant volume & $7 \%$ dan $10 \%$ \\
fraction & $60 \%-20 \%-20 \%$ \\
\hline Void fraction range & $0-40 \%$ \\
\hline \hline Maximum excess reactivity (\% dk/k) & $0,384 \%$ \\
\hline \hline Power Density & 34,2 watt/cc \\
\hline Active volume (litter) & $17.635,8$
\end{tabular}

\section{Conclusions}

Design study of long life(cycle) Boiling Water Reactor which can be operated for 20-30 years of operation time without the necessity of refuelling during that period has been performed. To achieve 20 years operational life time, addition Protactinium-231 which has huge capture cross section as Burnable Poisons can decrease maximum reactivity excess of the reactor core to $0.56 \% \mathrm{dk} / \mathrm{k}$ and increase operational life time of reactor core to 25 - 30 years.

Core with 17,635.8 litter volume which has 620 MW of power, operational time 30 , and maximum reactivity excess of $0.384 \% \mathrm{dk} / \mathrm{k}$, could be reached using the 8.1 - 11\% U-233 compositions and adding the $6.16-11.13 \% \mathrm{~Pa}-231$ as fuel.

Meanwhile, core with 5,193.034 litter volume which has $182 \mathrm{MW}$ of power, operational time 28, and maximum reactivity excess of $0.56 \% \mathrm{dk} / \mathrm{k}$, could be reached using the $10-13 \%$ composition of $U-233$ and adding the 9.36 - 16.01\% composition of $\mathrm{Pa}-231$ as fuel.

The use of gadolinium can also reduce maximum excess reactivity during burnup and the calculation results show that 12 years life time core without refuelling can be achieved with maximum excess reactivity of about $0.4 \% \mathrm{dk} / \mathrm{k}$. 


\section{References}

1. T. Imamura et al., Preliminary of ${ }^{231} \mathrm{~Pa}$ for Gas Gooled Long-Life Core, Ann. Nucl. Energy, 39, 226, 2000.

2. E. S. Riyana and Z. Su'ud, Preliminary Design Study of Thorium Cycle Based Tight Lattice Long Life BWR, COE-INES Indonesia International Symposium, 2005.
3. K. Takase et al., Behaviour in an Advanced Light-Water Reactor Core, JAERI, Japan, 2004

4. IAEA-TECDOC-1450, Thorium Fuel Cycle Potential Benefits and Challenges, 2005

5. K. Okumura, T. Kugo, K. Kaneko, and KK. Tsuchihashi, SRAC (Ver. 2002); The Comprehensive Neutronics Calculation Code System, Department of Nuclear Energy System, Japan Atomic Energy Research Institute (JAERI), 2002. 